\title{
On the potential application of polar and temperate marine microalgae for EPA and DHA production
}

\author{
Peter Boelen ${ }^{1 *}$, Roechama van Dijk1', Jaap S Sinninghe Damsté2 ${ }^{2}$ W Irene C Rijpstra² and Anita GJ Buma
}

\begin{abstract}
Long chain polyunsaturated fatty acids (LC-PUFAs) such as eicosapentaenoic acid (EPA) and docosahexaenoic acid (DHA) are considered essential omega-3 fatty acids in human nutrition. In marine microalgae EPA and/or DHA are allegedly involved in the regulation of membrane fluidity and thylakoid membrane functioning. The cellular content of EPA and DHA may therefore be enhanced at low temperature and irradiance conditions. As a result, polar and cold temperate marine microalgal species might potentially be suitable candidates for commercial EPA and DHA production, given their adaptation to low temperature and irradiance habitats.

In the present study we investigated inter- and intraspecific EPA and DHA variability in five polar and (cold) temperate microalgae. Intraspecific EPA and DHA content did not vary significantly in an Antarctic (Chaetoceros brevis) and a temperate (Thalassiosira weissflogii) centric diatom after acclimation to a range of irradiance levels at two temperatures. Interspecific variability was investigated for two Antarctic (Chaetoceros brevis and Pyramimonas sp. (Prasinophyceae)) and three cold-temperate species (Thalassiosira weissflogii, Emiliania huxleyi (Prymnesiophyceae) and Fibrocapsa japonica (Raphidophyceae)) during exponential growth. Interspecific variability was shown to be much more important than intraspecific variability. Highest relative and absolute levels of DHA were measured in the prymnesiophyte E. huxleyi and the prasinophyte Pyramimonas sp., while levels of EPA were high in the raphidophyte F. japonica and the diatoms C. brevis and T. weissflogii. Yet, no significant differences in LC-PUFA content were found between polar and cold-temperate species. Also, EPA and DHA production rates varied strongly between species. Highest EPA production rate $\left(174 \mathrm{\mu g} \mathrm{L}^{-1}\right.$ day $\left.{ }^{-1}\right)$ was found in the Antarctic diatom Chaetoceros brevis, while DHA production was highest in the cold-temperate prymnesiophyte Emiliania huxleyi $\left(164 \mathrm{\mu g} \mathrm{L}^{-1}\right.$ day $\left.{ }^{-1}\right)$. We show that, following careful species selection, effective mass cultivation of marine microalgae for EPA and DHA production may be possible under low temperature and irradiance conditions.
\end{abstract}

Keywords: Eicosapentaenoic acid, Docosahexaenoic acid, Thalassiosira weissflogii, Chaetoceros brevis, Fibrocapsa japonica, Emiliania huxleyi, Pyramimonas sp.

\section{Introduction}

Marine microalgae are key organisms in the production of long chain (between 14 and 22 carbon atoms) polyunsaturated fatty acids (LC-PUFAs) in marine food webs (Harwood and Jones 1989; Guschina and Harwood 2006). The most common LC-PUFAs found in marine microalgae are the omega-3 fatty acids eicosapentaenoic

\footnotetext{
* Correspondence: p.boelen@rug.nl

'Department of Ocean Ecosystems, Energy and Sustainability Research Institute, University of Groningen, Nijenborgh 7, Groningen, 9747 AG, The Netherlands

Full list of author information is available at the end of the article
}

acid (EPA, 20:5n3) and docosahexaenoic acid (DHA, 22:6n3), and, to a lesser extent, the omega- 6 fatty acid arachidonic acid (AA, 20:4n6). Both EPA and DHA are particularly found in taxa belonging to the Chromalveolata, such as diatoms, dinoflagellates and prymnesiophytes (Volkman et al. 1989; Tonon et al. 2002; Mansour et al. 2005).

EPA and DHA are considered essential elements in human nutrition. There are strong indications that LCPUFAs play an important role as membrane components involved in our neural system (Uauy et al. 2000). Furthermore, EPA and/or DHA function as hormone 
precursors and are thought to play a role in the immune system (Calder 1997; Uauy et al. 2000). Humans are able to synthesize EPA and DHA, but only at very low rates (Emken et al. 1994). EPA and DHA are formed from alpha-linoleic acid (ALA, 18:3n3), which is only present in substantial amounts in linseed oil and therefore almost completely missing in our diet (Ollis et al. 1999). As a result of this, there is a growing market for EPAand DHA-enriched products (e.g. in bread, margarine). Although microalgae are the primary producers of EPA and DHA in marine food webs, until now their principal source for human nutrition is marine fish oil (Sinclair 2000). To meet the needs of this market without further exploiting the world's fish stocks it is necessary to search for alternatives. Culturing microalgae is an economically profitable option and, moreover, due to their $\mathrm{CO}_{2}$ uptake, environmentally favorable. In addition, the production costs of DHA or EPA from cultured algae is potentially equal to the cost of producing EPA from fish oil (Milledge 2011). However, the efficiency should be further increased by selecting EPA- and/or DHA-rich species while at the same time optimizing mass cultivation and harvest conditions.

For long chain PUFAs, such as EPA and DHA, a major role in maintaining cell membrane fluidity is assumed (Nichols et al. 1993; Nishida and Murata 1996). For this reason, having elevated relative EPA and/or DHA levels could form a critical metabolic requirement for survival in polar regions, where microalgae typically live at temperatures near their freezing point (Thomas and Dieckmann 2002). Furthermore, EPA or other long chain PUFAs may play a role in the functioning of the thylakoid membrane and thus they are essential for photosynthesis (Kates and Volcani 1966; Cohen et al. 1988). At higher irradiance algae become less photosynthetically efficient and thus less thylakoid membranes are required. As a result, LC-PUFA content could be lower in high light-acclimated algae (Harwood and Jones 1989). In other words, cold-adapted polar microalgae might be good candidates for mass EPA and DHA production, since they can exhibit high growth rates under low temperature and irradiance conditions. Nevertheless earlier studies (e.g. Grima et al. 1995; Otero et al. 1997; Carvalho and Malcata 2005; Huerlimann et al. 2010) addressing the potential for EPA/DHA mass production focused primarily on warm (temperate) species. Although, in general, cultivation under high irradiance and temperature conditions will lead to higher growth rates (Raven and Geider 1988; Geider et al. 1998), this may not be optimal for LC-PUFA productivity. With respect to the intraspecific effect of irradiance and temperature earlier studies showed contradictive results. For example, the effect of irradiance was found to be strongly speciesspecific. In some of the studies the expected effect was found (Thompson et al. 1990; Guedes et al. 2010; Leu et al. 2010), but differences were often small while sometimes no or opposite irradiance effects were found (Chrismadha and Borowitzka 1994; Tzovenis et al. 1997; Carvalho and Malcata 2005; Zhukova 2007; Guiheneuf et al. 2009). Similarly, with respect to temperature, no consistent results were found (Thompson et al. 1992; Jiang and Gao, 2004; Teoh et al. 2004; Chen et al. 2008). Other factors influencing PUFA content suggested are $\mathrm{CO}_{2}$ concentration, nutrient availability, growth phase and day-night rhythm (Mayzaud et al. 1990; Yonmanitchai and Ward 1991; Zhukova 2004; Meiser et al. 2004; Lv et al. 2010). Besides intraspecific EPA and DHA variability, it is known that EPA and DHA content shows significant differences between and within algal classes. Each algal class has roughly its own fatty acid composition and the EPA-DHA content between algal classes is highly variable (Brown 2002; Guschina and Harwood 2006; Lv et al. 2010). Furthermore, as mentioned above, polar species are expected to sustain a higher EPA and DHA content, since their habitat is characterized by lower average irradiance and temperature levels (van Leeuwe 1997).

The aim of this study was first of all to get a better insight into the intraspecific variability in EPA and DHA content in response to irradiance and temperature. To investigate this, cellular EPA and DHA content of a polar and a temperate diatom was followed after acclimation to a range of irradiance levels at two temperatures. Secondly, the interspecific EPA and DHA variability between and within polar and temperate species was investigated. To this end, EPA and DHA content of two polar and three temperate species, cultured at equivalent growth conditions were investigated. So far, no comparative analysis between temperate and polar algal species had been carried out. In addition, many earlier studies reporting on EPA and DHA variability in polar species focused on relative variability, rather than on absolute cellular production rates. To be able to measure true interspecific differences, taking into account differences in total fatty acid content relative to algal biomass, the absolute amounts of EPA and DHA were determined, using biovolume as biomass unit.

\section{Materials and methods \\ Pre-experimental cultivation}

Two polar and three temperate species were selected representing different taxonomic groups (Table 1). Cultures of the polar species were maintained at $4^{\circ} \mathrm{C}$ and the temperate species at $16^{\circ} \mathrm{C}$, except for Fibrocapsa japonica, which was kept at $18^{\circ} \mathrm{C}$. Fibrocapsa japonica was cultured at an irradiance of $35 \mu \mathrm{mol}$ photons $\mathrm{m}^{-2}$ $\mathrm{s}^{-1}$. For the other species the pre-experimental culture irradiance was approximately $10 \mu \mathrm{mol}$ photons $\mathrm{m}^{-2} \mathrm{~s}^{-1}$. Before and during experimentation all species were 
Table 1 Details of investigated species and culturing conditions

\begin{tabular}{|c|c|c|c|c|c|}
\hline \multirow[b]{2}{*}{ Strain } & \multirow[b]{2}{*}{ Class } & \multirow[b]{2}{*}{ Strain\# } & \multirow[b]{2}{*}{ Biovolume $\left(\mu \mathrm{m}^{3}\right)$} & \multicolumn{2}{|c|}{ Culture conditions } \\
\hline & & & & Temperature $\left({ }^{\circ} \mathrm{C}\right)$ & Irradiance $\left(\mu \mathrm{mol}\right.$ photons $\left.\mathrm{m}^{-2} \mathrm{~s}^{-1}\right)$ \\
\hline Chaetoceros brevis & Bacillariophyceae & CCMP 163 & 351 & 3 and 7 & $10,25,75$ and 150 \\
\hline Thalassiosira weissflogii & Bacillariophyceae & CCMP 1049 & 2298 & 16 and 20 & $10,25,75$ and 150 \\
\hline Pyramimonas sp. & Prasinophyceae & RuG collection & 95 & 3 & 75 \\
\hline Emiliania huxleyi & Prymnesiophyceae & RuG collection & 35 & 16 & 75 \\
\hline Fibrocapsa japonica & Raphidophyceae & RuG collection & 4400 & 16 & 75 \\
\hline
\end{tabular}

subjected to a light-dark cycle of 16:8. Cultures were grown in F2 medium (Guillard and Ryther 1962) based on filtered natural sea water originating from the Canary Basin. For $F$. japonica the salinity of the medium was set at 25 PSU and for the other species at 35 PSU.

\section{Experimental setup}

Two sets of experiments were performed. Intraspecific variability in LC-PUFA content was investigated in a polar (Chaetoceros brevis) and a temperate (Thalassiosira weissflogii) centric diatom. Chaetoceros brevis was cultured at 3 and $7^{\circ} \mathrm{C}$ and $T$. weissflogii at $16^{\circ} \mathrm{C}$ and $20^{\circ} \mathrm{C}$, both at irradiances of $10,25,75$ and $150 \mu \mathrm{mol}$ photons $\mathrm{m}^{-2} \mathrm{~s}^{-1}$. The irradiance levels were based on earlier experiments on Antarctic and cold temperate phytoplankton (van de Poll et al. 2007; Boelen et al. 2011) and simulate limiting and saturating culture conditions in a stable water column. Interspecific LC-PUFA variability was investigated for two polar (C. brevis and Pyramimonas sp.) and three temperate (F. japonica, T. weissflogii and Emiliania huxleyi) species. For the latter set of experiments all species were cultured at the same irradiance $\left(75 \mu \mathrm{mol}\right.$ photons $\left.\mathrm{m}^{-2} \mathrm{~s}^{-1}\right)$ at $16^{\circ} \mathrm{C}$ for the temperate species and $3^{\circ} \mathrm{C}$ for the polar species. Algae were cultured in duplicate in Fernbach or Erlenmeyer flasks with a working volume of approximately $0.5 \mathrm{~L}$. The experiments were set up in water baths, connected to Neslab cryostats, to assure accurate temperature control $\left( \pm 0.5^{\circ} \mathrm{C}\right)$. Before samples were collected for fatty acid and pigment analysis (see below), cultures were acclimated to the different temperatures and irradiance levels in semi-continuous batch mode for at least one week; fast growing cultures were diluted with fresh medium to avoid nutrient limitation. Sampling took place during exponential growth in the middle of the light period. Cell counts were done regularly to establish growth rates. Specific growth rates $(\mu)$ were calculated from linear regressions of the natural log of cell numbers versus time. Cell biovolumes were calculated from microscopic images as described below.

\section{Analytical procedures}

Cell numbers were determined using a Coulter XL-MCL flow cytometer (Beckman Coulter, Miami, FL, USA) as described by van de Poll et al. (2005).
To determine the pigment composition, samples of cultures $(30 \mathrm{~mL})$ were filtered through GF/F filters (25 $\mathrm{mm})$, immediately frozen in liquid nitrogen and stored at $-80^{\circ} \mathrm{C}$ until further analysis. The filters were freezedried (48 h) and extracted with 90\% (aqueous) acetone for $48 \mathrm{~h}$ at $4^{\circ} \mathrm{C}$. Pigments were separated and quantified on a Waters HPLC system (model 2690) equipped with a 996 photodiode array detector and a $\mathrm{C}_{18} 5 \mu \mathrm{m}$ DeltaPak reverse-phase column as described by van Leeuwe et al. (2006).

For fatty acid analysis, $100 \mathrm{~mL}$ of the culture were filtered through pre-combusted GF/F (25 mm) filters, frozen in liquid nitrogen and stored at $-80^{\circ} \mathrm{C}$ until further analysis using gas chromatography (GC) and gas chromatography-mass spectrometry (GC-MS). The procedure is modified from the method described by Klein Breteler et al. (2004). The samples were freeze-dried for $48 \mathrm{~h}$ and a known amount of nonadecanoic acid (C19:0, Fluka) was added as an internal standard. The samples were saponified by reflux ( $1 \mathrm{~h})$ with $1 \mathrm{~N} \mathrm{KOH}-\mathrm{MeOH}$ (96\%). After acidifying with $2 \mathrm{~N} \mathrm{HCl}-\mathrm{MeOH}(1: 1)$ to a $\mathrm{pH}$ of 4 the filter was removed by centrifugation and bidistilled water was added to the supernatant in a ratio equal to $\mathrm{MeOH}$. Fatty acids were extracted from this mixture with dichloromethane (DCM) $(3 \times)$. The DCM extract was dried over $\mathrm{Na}_{2} \mathrm{SO}_{4}$ and methylated with diazomethane. The non-polar fatty acid methyl esters were separated from the polar compounds over a small $\mathrm{Al}_{2} \mathrm{O}_{3}$ column using DCM as eluent and analyzed on a Hewlett-Packard 6890 gas chromatograph equipped with a fused silica capillary column $(50 \mathrm{~m} \times 0.32 \mathrm{~mm})$ coated with CP Sil-5 CB (film thickness $0.12 \mu \mathrm{m}$ ). Helium was used as carrier gas. The oven thermal gradient rose from an initial $70^{\circ} \mathrm{C}$ to $130^{\circ} \mathrm{C}$ at $20^{\circ} \mathrm{C} \mathrm{min}^{-1}$ and then to a final temperature of $320^{\circ} \mathrm{C}$ increasing $4^{\circ} \mathrm{C}$ $\min ^{-1}$, which was maintained for $10 \mathrm{~min}$. Selected samples were also analyzed by GC-MS. GC-MS was performed with a Hewlett-Packard 5890 gas chromatograph interfaced with a VG Autospec Ultima mass spectrometer operating at $70 \mathrm{eV}$, with a mass range of $\mathrm{m} / \mathrm{z}$ 50-800 and a cycle time of $1.7 \mathrm{~s}$ (resolution 1000). The gas chromatograph was equipped with an on-column injection system and the same capillary column as described for GC. The carrier gas was helium. The 
temperature program was the same as described for GC. Long chain fatty acids (number of carbons $\geq 14$ ) were identified from mass spectra and retention times and the double-bond positions were determined by comparison with those of PUFA No.1 standard mixture (Matreya). Quantification of fatty acids was done by integration of appropriate peak areas and using the known concentration of the added internal standard.

To calculate the biovolume of the algae, a sample of about $2 \mathrm{ml}$ culture was analyzed using an inverted microscope. The sizes of 50 cells were measured and biovolume (Table 1) was calculated according to Hillebrand et al. (1999) assuming a cylinder for C. brevis and T. weissflogii, halve an ellipse for Pyramimonas sp., and a sphere for Emiliania huxleyi. The biovolume of $F$. japonica was taken from de Boer (2006).

EPA and DHA production rates $\left(\mathrm{P}_{\text {PUFA }}\left[\mu \mathrm{g} \mathrm{L}^{-1}\right.\right.$ day $\left.\left.^{-1}\right]\right)$ were calculated from specific growth rate $\left(\mu\left[\right.\right.$ day $\left.\left.^{-1}\right]\right)$, cellular EPA or DHA content $\left(C_{\text {PUFA }}\left[\mu \mathrm{g} \mathrm{cell}^{-1}\right]\right)$ and maximum cell density $\left(\mathrm{N}_{\mathrm{m}}\right.$ [cells $\left.\left.\mathrm{L}^{-1}\right]\right)$ according to the equation $\mathrm{P}_{\text {PUFA }}=\mu \times \mathrm{C}_{\text {PUFA }} \times \mathrm{N}_{\mathrm{m}}$. Since maximum cell densities were not the same at all culture conditions, the calculations were based on averages of final cell numbers at harvest in cultures grown at standard irradiance conditions $\left(75 \mu \mathrm{mol}\right.$ photons $\left.\mathrm{m}^{-2} \mathrm{~s}^{-1}\right)$.

\section{Statistical analysis}

Significant differences between treatments were analyzed with a one-way analysis of variance (ANOVA) and were considered not significant at $p>0.05$. Posthoc tests (Tukey HSD) were performed to further specify differences.

\section{Results}

\section{Effect of temperature and irradiance}

For both investigated species, C. brevis and T. weissflogii, growth rates and chlorophyll a levels were clearly influenced by irradiance levels; growth rates increased at increasing irradiance levels, while chlorophyll $a$ content per cell was significantly higher at low irradiance (Table 2). For the polar diatom $C$. brevis no significant effect of temperature on growth rate and chlorophyll $a$ could be demonstrated. For $T$. weissflogii a small but significant effect of temperature on chlorophyll $a$ content was found, being slightly higher at $16^{\circ} \mathrm{C}$ (standard culture temperature) compared to $20^{\circ} \mathrm{C}$ (Table 2). The effect of temperature on specific growth rate was not

Table 2 Chlorophyll a per cell, specific growth rate ( $\mu$ ), EPA and DHA content (normalized to biovolume) of two polar (C. brevis, Pyramimonas sp.) and three temperate (T. weissflogii, E. huxleyi and F. japonica) microalgal species (mean value ( \pm SD) of two replicate cultures)

\begin{tabular}{|c|c|c|c|c|c|c|}
\hline & $\begin{array}{c}\text { Temperature } \\
\left({ }^{\circ} \mathrm{C}\right)\end{array}$ & $\begin{array}{c}\text { Irradiance } \\
\left(\mu \mathrm{mol} \mathrm{m} \mathrm{m}^{-2} \mathrm{~s}^{-1}\right)\end{array}$ & $\mu\left(\right.$ day $\left.^{-1}\right)$ & $\begin{array}{l}\text { Chloroph. } a \\
\left(\text { pg cell }^{-1}\right)\end{array}$ & $\begin{array}{c}\text { EPA content } \\
\left(\mathrm{fg} \mu \mathrm{m}^{-3}\right)\end{array}$ & $\begin{array}{l}\text { DHA content } \\
\left(\mathrm{fg} \mu \mathrm{m}^{-3}\right)\end{array}$ \\
\hline \multirow[t]{8}{*}{ Chaetoceros brevis } & 3 & 10 & $0.22 \pm 0.02$ & $0.50 \pm 0.03$ & $1.62 \pm 0.03$ & $0.04 \pm 0.00$ \\
\hline & 3 & 25 & $0.35 \pm 0.02$ & $0.39 \pm 0.02$ & $1.56 \pm 0.45$ & $0.03 \pm 0.01$ \\
\hline & 3 & 75 & $0.47 \pm 0.01$ & $0.15 \pm 0.01$ & $1.06 \pm 0.06$ & $0.02 \pm 0.00$ \\
\hline & 3 & 150 & $0.43 \pm 0.02$ & $0.15 \pm 0.00$ & $1.18 \pm 0.05$ & $0.03 \pm 0.00$ \\
\hline & 7 & 10 & $0.24 \pm 0.03$ & $0.52 \pm 0.06$ & $1.61 \pm 0.14$ & $0.03 \pm 0.00$ \\
\hline & 7 & 25 & $0.36 \pm 0.06$ & $0.44 \pm 0.11$ & $1.19 \pm 0.48$ & $0.02 \pm 0.02$ \\
\hline & 7 & 75 & $0.41 \pm 0.00$ & $0.13 \pm 0.01$ & $1.23^{*}$ & $0.03^{*}$ \\
\hline & 7 & 150 & $0.42 \pm 0.02$ & $0.13 \pm 0.00$ & $1.52 \pm 0.07$ & $0.03 \pm 0.01$ \\
\hline \multirow{8}{*}{$\begin{array}{l}\text { Thalassiosira } \\
\text { weissflogii }\end{array}$} & 16 & 10 & $0.29 \pm 0.06$ & $9.77 \pm 0.03$ & $2.23^{*}$ & $0.34^{*}$ \\
\hline & 16 & 25 & $0.36 \pm 0.01$ & $9.84 \pm 0.70$ & nd & nd \\
\hline & 16 & 75 & $0.42 \pm 0.08$ & $4.50 \pm 1.14$ & $2.31 \pm 0.26$ & $0.43 \pm 0.05$ \\
\hline & 16 & 150 & $0.49 \pm 0.09$ & $3.05 \pm 0.00$ & $1.85 \pm 0.13$ & $0.35 \pm 0.07$ \\
\hline & 20 & 10 & $0.31 \pm 0.01$ & $9.53 \pm 0.06$ & $1.61 \pm 0.08$ & $0.27 \pm 0.01$ \\
\hline & 20 & 25 & nd & $8.40 \pm 0.33$ & $1.83 \pm 0.01$ & $0.34 \pm 0.00$ \\
\hline & 20 & 75 & nd & $3.67 \pm 0.38$ & nd & nd \\
\hline & 20 & 150 & nd & $2.93 \pm 0.09$ & $1.99^{*}$ & $0.40^{*}$ \\
\hline Pyramimonas sp. & 3 & 75 & $0.14 \pm 0.03$ & $1.54 \pm 0.16$ & 0 & $8.75 \pm 0.28$ \\
\hline Emiliania huxleyi & 16 & 75 & $0.34 \pm 0.08$ & $0.18 \pm 0.00$ & $0.89 *$ & $27.7^{*}$ \\
\hline Fibrocapsa japonica & 16 & 75 & $0.44 \pm 0.04$ & $15.99 \pm 0.71$ & $2.93 \pm 0.30$ & 0 \\
\hline
\end{tabular}

Standard culture conditions are indicated in bold. $\mathrm{nd}=$ no data available. ${ }^{*}$ no replicate. 
determined for this species. Since chlorophyll $a$ levels were affected by irradiance and temperature, standard biovolume values were used as biomass units. No significant effect of temperature and irradiance on EPA and DHA content could be demonstrated for both species (Figure 1, Table 2).

\section{Interspecific PUFA variability}

The fatty acid composition showed large variability between species, cultured at standard irradiance $(75 \mu \mathrm{mol}$ photons $\left.\mathrm{m}^{-2} \mathrm{~s}^{-1}\right)$ and temperature $\left(3^{\circ} \mathrm{C}\right.$ and $16^{\circ} \mathrm{C}$ for polar and temperate species, respectively) (Table 3 ). Relative amounts of long chain PUFAs, expressed as percent of total long chain fatty acids (number of carbons $\geq 14$ ), varied between $34-62 \%$. EPA and DHA content varied strongly between species. In $F$. japonica and the diatoms $C$. brevis and T. weisflogii high abundances (between 12-32\%) of EPA were detected, while levels of DHA were low $(<3 \%)$. In contrast, E. huxleyi contained high relative proportions of DHA (21\%) and minimal $(<1 \%)$ amounts of EPA. Other PUFAs present in substantial amounts were a 16:4 polyunsaturated fatty acid (C. brevis and Pyramimonas sp. only), alphalinolenic acid (ALA; 18:3(n-3)) (Pyramimonas sp. and $E$. huxleyi). In Pyramimonas sp. also small amounts (3\%) of docosapentaenoic acid (DPA; 22:5(n-3)) were found.

The highest absolute amount of DHA normalized to biovolume was measured in the prymnesiophyte E. huxleyi (27.7 fg DHA $\mu \mathrm{m}^{-3}$ ), followed by the Antarctic prasinophyte Pyramimonas sp. (8.75 fg DHA $\mu^{-3}$ ) (Table 2). Relatively low DHA levels were observed for the Antarctic diatom Chaetoceros brevis $\left(0.02 \mathrm{fg}\right.$ DHA $\left.\mu \mathrm{m}^{-3}\right)$, while DHA was undetectable in the raphidophyte Fibrocapsa japonica (Table 2). When normalized to biovolume, absolute EPA

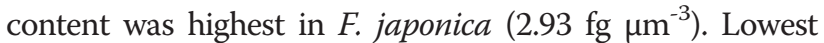
EPA levels were found in Emiliania huxleyi (0.89 fg EPA $\mu^{-3}$ ) while EPA was undetectable in Pyramimonas sp.. Overall, DHA levels showed the highest interspecific

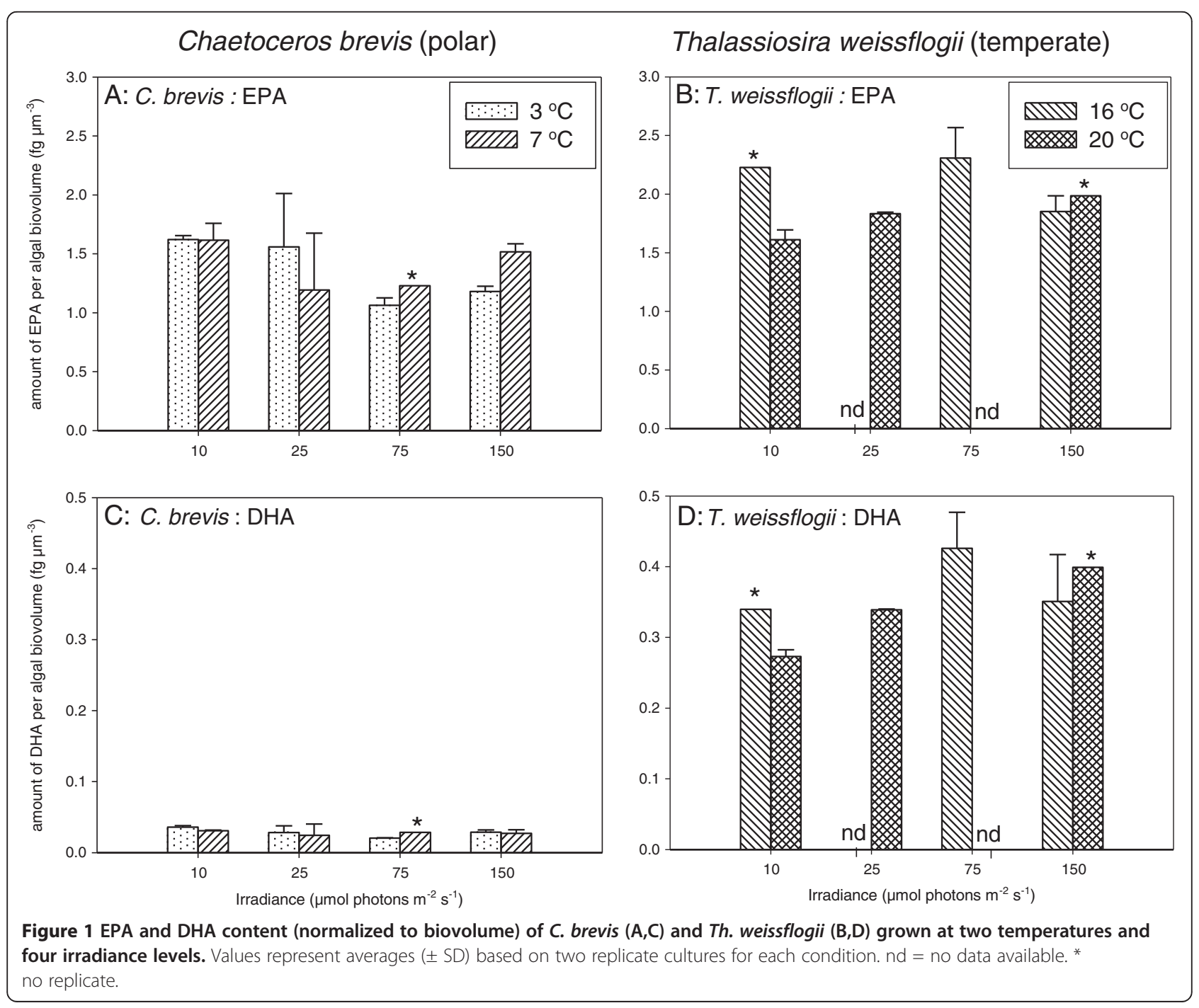


Table 3 Fatty acid composition (\% of total long chain fatty acid) of the five investigated species, cultivated at standard irradiance $\left(75 \mu \mathrm{mol}\right.$ photons $\mathrm{m}^{-2} \mathrm{~s}^{-1}$ ) and temperature (polar species: $3^{\circ} \mathrm{C}$, temperate species: $16^{\circ} \mathrm{C}$ ) conditions

\begin{tabular}{|c|c|c|c|c|c|}
\hline Fatty acid & Chaetoceros brevis & Thalassiosira weissflogii & Pyramimonas sp. & Emiliania huxleyi* & Fibrocapsa japonica \\
\hline C14:0 & $7.6 \pm 0.1$ & $7.6 \pm 0.4$ & - & 20.2 & $22.1 \pm 0.1$ \\
\hline C15:0 & - & $1.3 \pm 0.1$ & - & 1.1 & - \\
\hline C16:0 & $7.9 \pm 0.1$ & $26.8 \pm 0.3$ & $23.2 \pm 0.3$ & 6.2 & $18.6 \pm 0.2$ \\
\hline C16:1 & $2.8 \pm 0.0$ & - & $1.5 \pm 0.0$ & - & $1.5 \pm 0.1$ \\
\hline C16:1n7 & $26.6 \pm 0.1$ & $30.2 \pm 0.4$ & - & - & $2.7 \pm 0.8$ \\
\hline C16:3 & $3.4 \pm 0.1$ & $11.9 \pm 0.1$ & - & - & - \\
\hline C16:4 & $14.2 \pm 0.4$ & - & $18.9 \pm 1.0$ & - & - \\
\hline C18:0 & - & - & $2.6 \pm 1.8$ & - & $1.4 \pm 0.3$ \\
\hline C18:1n5 & - & - & $2.8 \pm 0.1$ & 3.0 & - \\
\hline C18:1n7 & - & - & $5.5 \pm 0.1$ & 4.4 & $9.2 \pm 3.0$ \\
\hline C18:1n9 & - & - & $2.9 \pm 0.1$ & 17.1 & $10.9 \pm 0.4$ \\
\hline C18:2n6 & - & - & $3.8 \pm 0.0$ & 2.1 & $4.8 \pm 0.0$ \\
\hline C18:3n3 & - & - & $17.1 \pm 0.4$ & 8.9 & $2.2 \pm 0.2$ \\
\hline C18:4n3 & $5.6 \pm 0.1$ & $5.0 \pm 0.3$ & $5.9 \pm 0.2$ & 7.9 & $7.8 \pm 2.1$ \\
\hline C18:5n3 & - & - & $4.9 \pm 0.2$ & 8.4 & - \\
\hline$C 20: 3$ & - & - & $2.8 \pm 0.1$ & - & - \\
\hline C20:4n6 & - & - & - & - & $7.3 \pm 0.6$ \\
\hline C20:5n3 (EPA) & $31.5 \pm 0.4$ & $14.6 \pm 0.1$ & - & - & $11.9 \pm 1.5$ \\
\hline$C 22: 5 n 3$ & - & - & $2.6 \pm 0.1$ & - & - \\
\hline C22:6n3 (DHA) & - & $2.7 \pm 0.0$ & $5.8 \pm 0.3$ & 20.7 & - \\
\hline
\end{tabular}

Values represent averages $( \pm S D)$ based on two replicate cultures. ${ }^{*}$ no replicate. $-<1 \%$.

variability, varying two orders of magnitude on a biovolume basis (Table 2).

Although interspecific differences in EPA and DHA were substantial, no significant differences in relative and absolute amounts of EPA and DHA were observed between polar and temperate species.

\section{EPA and DHA production rates}

Volumetric EPA and DHA productivity was calculated from cellular PUFA content, specific growth rates and maximal cell numbers (Table 4). Although in F. japonica EPA content per biovolume was highest (Table 2), total biomass production was higher in the Antarctic $C$. brevis leading to highest EPA productivity (at standard culture conditions circa $174 \mu \mathrm{g} \mathrm{L}^{-1}$ day $^{-1}$ ). The small prymnesiophyte E. huxleyi showed the highest DHA productivity $\left(164 \mu \mathrm{g} \mathrm{L}^{-1} \mathrm{~d}^{-1}\right)$, even though growth rate and maximal biomass were relatively low in this species.

For $C$. brevis and T. weissflogii EPA productivity was reduced at the lowest irradiance conditions, mainly due light limitation leading to reduced growth rates. For C. brevis no significant effect of temperature on EPA and DHA productivity could be demonstrated.

\section{Discussion}

In this study we focused on EPA and DHA content and productivity in polar and (cold) temperate marine microalgae with an eye towards future high-latitude mass cultivation. With the method we have used for fatty acid analysis we did not distinguish between intracellular free fatty acids or those derived from triacylglycerols (TAGs), glycolipids or other lipid classes. This would compromise comparison with other studies focusing on fatty acids derived from extracted lipids (e.g. Lang et al. 2011), on LC-PUFA production in TAGs (Tonon et al. 2002) or on fatty acid profiles derived from specific lipid classes (Guckert et al. 1988).

The present study demonstrates large species-specific variability in EPA and DHA content, while irradiance and temperature showed relatively little to no effect. Highest relative and absolute levels of DHA were measured in the cold temperate prymnesiophyte E. huxleyi and the Antarctic prasinophyte Pyramimonas sp., while levels of EPA were high in the raphidophyte $F$. japonica and the diatoms $C$. brevis and T. weissflogii. Similar relative EPA and DHA compositions were found before for F. japonica (Mostaert et al. 1998; Marshall et al. 2002), E. huxleyi (Viso and Marty 1993; Bell and Pond 1996; Lang et al. 2011) and T. weissflogii (Viso and Marty 
Table 4 Calculated EPA and DHA production rates $\left(\mu \mathrm{g} \mathrm{L}^{-1}\right.$ day $\left.^{-1}\right)$ during exponential growth for five species of microalgae based on specific growth rates and cellular PUFA content values from Table 2

\begin{tabular}{|c|c|c|c|c|c|}
\hline & \multirow{2}{*}{$\begin{array}{c}\text { Irradiance } \\
\left(\mu \mathrm{mol} \mathrm{m}{ }^{-2} \mathrm{~s}^{-1}\right)\end{array}$} & \multicolumn{2}{|c|}{$E P A\left(\mu g L^{-1}\right.$ day $\left.^{-1}\right)$} & \multicolumn{2}{|c|}{$D H A\left(\mu g L^{-1}\right.$ day $\left.^{-1}\right)$} \\
\hline & & LT & HT & LT & $\mathrm{HT}$ \\
\hline \multirow[t]{4}{*}{ Chaetoceros brevis } & 10 & $125 \pm 14$ & $138 \pm 31$ & $3 \pm 0$ & $3 \pm 0$ \\
\hline & 25 & $193 \pm 68$ & $160 \pm 84$ & $4 \pm 1$ & $3 \pm 2$ \\
\hline & 75 & $174 \pm 14$ & $176 \pm 0.7$ & $3 \pm 0$ & $4 \pm 0$ \\
\hline & 150 & $175 \pm 14$ & $223 \pm 20$ & $4 \pm 1$ & $4 \pm 1$ \\
\hline \multirow[t]{3}{*}{ Thalassiosira weissflogii } & 10 & $76 \pm 17$ & $60 \pm 6$ & $12 \pm 3$ & $10 \pm 1$ \\
\hline & 75 & $119 \pm 36$ & nd & $22 \pm 7$ & nd \\
\hline & 150 & $110 \pm 27$ & nd & $21 \pm 7$ & nd \\
\hline Pyramimonas sp. & 75 & 0 & nd & $5 \pm 1$ & nd \\
\hline Emiliania huxleyi & 75 & $5 \pm 1$ & nd & $164 \pm 41$ & nd \\
\hline Fibrocapsa japonica & 75 & $150 \pm 30$ & nd & 0 & nd \\
\hline
\end{tabular}

Standard culture conditions are indicated in bold. LT: culture temperature $3^{\circ} \mathrm{C}$ (polar species: C. brevis, Pyramimonas sp.) or $16^{\circ} \mathrm{C}$ (temperate species: . weissflogii, E. hux and F. japonica). HT: culture temperature $7^{\circ} \mathrm{C}$ (polar species) or $20^{\circ} \mathrm{C}$ (temperate species). Cell densities at harvest: C. brevis: $9.9 \times 10^{5}$ cells $\mathrm{mL}^{-1}, T$. weissflogii: $5.2 \times 10^{4}$ cells mL $\mathrm{mL}^{-1}$, Pyramimonas sp.: $4.5 \times 10^{4}$ cells $\mathrm{mL}^{-1}$, E. hux $5.0 \times 10^{5}$ cells mL ${ }^{-1}$, and F. japonica: $2.6 \times 10^{4}$ cells $\mathrm{mL}^{-1}$. Values represent averages \pm standard deviation of two replicate cultures. $\mathrm{nd}=$ no data available.

1993). In contrast, Lang et al. (2011) could not detect EPA as well as DHA in a $T$. weissflogii strain isolated from a brackish habitat. Although in general green algae do not contain high amounts of EPA and DHA, this is not the case for some marine Chlorella (Watanabe et al. 1983) and prasinophyte species (Viso and Marty 1993; Dunstan et al. 1992). In our study and in the study by Dunstan et al. (1992) relatively high amounts of DHA were found for the prasinophyte Pyramimonas sp.

Many earlier studies focused primarily on relative PUFA composition. Yet, Viso and Marty (1993) examined absolute fatty acid abundance and $\mathrm{C} / \mathrm{N}$ ratios of 28 temperate marine microalgae from nine taxonomic classes, allowing the comparison of absolute PUFA content in terms of pg PUFA per cell. In our study EPA levels in the (cold) temperate species $T$. weissflogii varied between between 3.7 and $5.3 \mathrm{pg} \mathrm{cell}^{-1}$, while E. huxleyi contained a maximum DHA amount of $1.0 \mathrm{pg}$ cell $^{-1}$. Our levels were circa 10 times higher than EPA or DHA levels measured by Viso and Marty (1993) for these species (0.38 pg EPA cell ${ }^{-1}$ in $T$. weissflogii and 0.14 pg DHA cell $^{-1}$ in $E$. huxleyi). This implies that the potential use of these species for future EPA/DHA production might be higher than earlier expected.

It has been postulated that microorganisms from polar regions contain relatively high (long chain) PUFA levels to maintain cell membrane fluidity (Nichols et al. 1993; Nishida and Murata 1996), but this was not confirmed by our study. For example, biovolume normalized EPA levels were higher in the polar diatom $C$. brevis than in the temperate diatom $T$. weissfloggii, whereas DHA levels were higher in the latter species. Also, no significant intraspecific effect of temperature on EPA or DHA content was found for the two investigated diatoms C. brevis and T. weisflogii. Thompson et al. (1992) studied the effect of temperature over the range from 10 to $25^{\circ} \mathrm{C}$ on fatty acid composition of eight species of marine phytoplankton, including Thalassiosira pseudonana and three species within the genus Chaetoceros. Pooled data from all species indicated a weak trend towards elevated PUFAs at lower temperature. However, only for $T$. pseudonana the percentage of the essential fatty acid DHA decreased linearly with increasing temperature. In addition, other studies (e.g. Teoh et al. 2004; Rousch 2003) showed varying results. Here a complicating factor could be that in many studies, including the present study, the distribution of PUFAs into the different lipid classes was not determined. Chen et al. (2008) suggested that low temperature could change the distribution of PUFAs in phospholipids, which contain high percentages of EPA and DHA, while at the same time not significantly affecting their total amount.

Since PUFAs play a role in the functioning of the thylakoid membrane, irradiance might theoretically affect (LC)-PUFA content in marine microalgae. In some studies light intensity indeed was negatively correlated with PUFA content (Thompson et al. 1990; Guedes et al. 2010; Leu et al. 2010), but the effect was often small, while sometimes no or a positive irradiance effect was found (e.g. Chrismadha and Borowitzka 1994; Tzovenis et al. 1997; Carvalho and Malcata 2005; Zhukova 2007; Guiheneuf et al. 2009). In our study no significant effect of irradiance on LC-PUFA content could be demonstrated for the two investigated diatoms $C$. brevis and $T$. weissflogii, while for both species chlorophyll $a$ levels were clearly influenced by irradiance, indicating photoacclimation to the applied irradiance levels.

PUFA composition and production rate were found to be strongly species specific in our study. For example, 
the highest daily EPA production rate was found in the Antarctic diatom Chaetoceros brevis, while DHA production was highest in the cold-temperate prymnesiophyte Emiliania huxleyi. These results are consistent with earlier findings that EPA and DHA content differs systematically between taxonomic groups (Brown 2002). This implies that EPA and DHA productivity in algal mass cultures first of all benefits from thorough species selection: Mass cultivation at low temperature would benefit greatly from the relatively high growth rates exhibited by polar species at these low temperatures (C. brevis: $0.47 \mathrm{~d}^{-1}$ at $3^{\circ} \mathrm{C}$, compared to $T$. weissflogii at $16^{\circ} \mathrm{C}: 0.49 \mathrm{~d}^{-1}$ ), while having similar LC-PUFA contents. Secondly, EPA and DHA production will gain primarily from the enhancement of growth rates or cell densities rather than from temperature or light-induced shifts in cellular EPA or DHA. EPA and DHA production rates determined in this study were lower than values reported elsewhere. For example, Meiser et al. (2004) cultured Phaeodactylum tricornutum in a flat panel airlift photobioreactor at high irradiance $\left(1000 \mu \mathrm{mol}\right.$ photons $\mathrm{m}^{-2}$ $\mathrm{s}^{-1}, 24 \mathrm{~h} \mathrm{day}^{-1}$ ) and increased $\mathrm{CO}_{2}$ concentration resulting in a maximal EPA productivity of $118 \mathrm{mg} \mathrm{L}^{-1}$ day $^{-1}$, which is circa 700 times higher than maximal productivity values from this study. Carvalho and Malcata (2005) reported a maximal productivity in Pavlova lutheri of $3.6 \mathrm{mg} \mathrm{L}^{-1}$ day ${ }^{-1}$ for EPA and $1.3 \mathrm{mg} \mathrm{L}^{-1} \mathrm{day}^{-1}$ for DHA, which is circa 8 times higher than the DHA productivity values we determined for E. huxleyi. However, in our study we did not aim to optimize growth rates and cell densities for the individual species under study: our goal was to compare temperature and irradiance effects on PUFA composition in dilute cultures under standardized, nutrient replete conditions at sub-optimal temperatures.

We conclude that effective, low temperature mass cultivation of marine algae for EPA and DHA production would benefit from careful target species selection. Subsequently, for optimizing EPA/DHA yield merely specific growth rate needs to be considered rather than intracellular PUFA variability. In this respect, polar species cannot be ruled out per se since cold adapted algal species can exhibit high growth rates while at the same time synthesizing high EPA and/or DHA levels.

\section{Competing interests}

The authors declare that they have no competing interests.

\section{Acknowledgements}

Thanks are due to Willem van de Poll for help with the flow cytometer, Ronald Visser for the pigment analyses and Karin de Boer and Loes Venekamp for culture maintenance.

\footnotetext{
Author details

${ }^{1}$ Department of Ocean Ecosystems, Energy and Sustainability Research Institute, University of Groningen, Nijenborgh 7, Groningen, 9747 AG, The Netherlands. ${ }^{2}$ Department of Marine Organic Biogeochemistry, Royal Netherlands Institute for Sea Research (NIOZ), Landsdiep 4, 1797 SZ, 't Horntje, Texel, The Netherlands.
}

Received: 18 March 2013 Accepted: 10 May 2013

Published: 14 May 2013

\section{References}

Bell MV, Pond D (1996) Lipid composition during growth of motile and coccolith forms of Emiliania huxleyi. Phytochemistry 41:465-471

Boelen P, Van de Poll WH, Van der Strate HJ, Neven IA, Beardall J, Buma AGJ (2011) Neither elevated nor reduced CO2 affects the photophysiological performance of the marine Antarctic diatom Chaetoceros brevis. J Exp Mar Biol Ecol 406:38-45

Brown MR (2002) Nutritional value of microalgae for aquaculture. In: Cruz-Suárez LE, Ricque-Marie D, Tapia-Salazar M, Gaxiola-Cortés MG, Simoes N (eds) Avances en nutrición acuícola VI. Memorias del VI Simposio Internacional de Nutrición Acuícola. 3 al 6 de Septiembre de 2002. Universidad Autónoma de Nuevo León, Monterrey, N.L., México, pp 281-292. ISBN 970-694090-1

Calder PC (1997) n-3 Polyunsaturated fatty scids and cytokine production in health and disease. Ann Nutr Metab 41:203-234

Carvalho AP, Malcata FX (2005) Optimization of omega-3 fatty acid production by microalgae: Crossover effects of $\mathrm{CO}_{2}$ and light intensity under batch and continuous cultivation modes. Mar Biotechnol 7:381-388

Chen G, Jiang Y, Chen F (2008) Variation of lipid class composition in Nitzschia laevis as a response to growth temperature change. Food Chem 109:88-94

Chrismadha T, Borowitzka MA (1994) Effect of cell-density and irradiance on growth, proximate composition and eicosapentaenoic acid production of Phaeodactylum tricornutum grown in a tubular photobioreactor. J Appl Phycol 6:67-74

Cohen Z, Vonshak A, Richmond A (1988) Effect of environmental conditions on fatty acid composition of the red alga Porphyridium cruentum: correlation to growth. J Phycol 2:328-332

de Boer MK (2006) Maze of toxicity: Fibrocapsa japonica (Raphidophyceae) in dutch coastal waters, PhD thesis. University of Groningen, The Netherlands

Dunstan GA, Volkman JK, Jeffrey SW, Barrett SM (1992) Biochemical composition of microalgae from the green algal classes Chlorophyceae and Prasinophyceae. 2. Lipid classes and fatty acids. J Exp Mar Biol Ecol 161:115-134

Emken EA, Adlof RO, Gulley RM (1994) Dietary linoleic-acid influences desaturation and acylation of deuterium-labeled linoleic and linolenic acids in young-adult males. Biochim Biophys Acta 1213:277-288

Geider RJ, Maclntyre HL, Kana TM (1998) A dynamic regulatory model of phytoplanktonic acclimation to light, nutrients, and temperature. Limnol Oceanogr 43:679-694

Grima EM, Perez JAS, Camacho FG, Sevilla JMF, Fernandez FGA, Cardona JU (1995) Biomass and icosapentaenoic acid productivities from an outdoor batch culture of Phaeodactylum tricornutum UTEX 640 in an airlift tubular photobioreactor. Appl Microbiol Biotechnol 42:658-663

Guckert J, Cooksey K, Jackson L (1988) Lipid solvent systems are not equivalent for analysis of lipid classes in the microeukaryotic green alga, Chlorella. Jicrobiol Methods 8:139-149

Guedes AC, Meireles LA, Amaro HM, Malcata FX (2010) Changes in lipid class and fatty acid composition of cultures of Pavlova lutheri, in response to light intensity. J Am Oil Chem Soc 87:791-801

Guiheneuf F, Mimouni V, Ulmann L, Tremblin G (2009) Combined effects of irradiance level and carbon source on fatty acid and lipid class composition in the microalga Pavlova lutheri commonly used in mariculture. J Exp Mar Biol Ecol 369:136-143

Guillard RRL, Ryther JH (1962) Studies of marine planktonic diatoms.I. Cyclotella nana hustedt, and Detonula confervacea (Cleve) Gran. Can J Microbiol 8:229-239

Guschina IA, Harwood JL (2006) Lipids and lipid metabolism in eukaryotic algae. Prog Lipid Res 45:160-186

Harwood JL, Jones AL (1989) Lipid-metabolism in algae. Adv Bot Res 16:1-53

Hillebrand H, Durselen CD, Kirschtel D, Pollingher U, Zohary T (1999) Biovolume calculation for pelagic and benthic microalgae. J Phycol 35:403-424

Huerlimann R, de Nys R, Heimann K (2010) Growth, lipid content, productivity, and fatty acid composition of tropical microalgae for scale-up production. Biotechnol Bioeng 107:245-57

Jiang HM, Gao KS (2004) Effects of lowering temperature during culture on the production of polyunsaturated fatty acids in the marine diatom Phaeodactylum tricornutum (Bacillariophyceae). J Phycol 40:651-654

Kates M, Volcani BE (1966) Lipid components of diatoms. Biochim Biophys Acta 116:264-78 
Klein Breteler W, Koski M, Rampen S (2004) Role of essential lipids in copepod nutrition: no evidence for trophic upgrading of food quality by a marine ciliate. Mar Ecol Prog Ser 274:199-208

Lang I, Hodac L, Friedl T, Feussner I (2011) Fatty acid profiles and their distribution patterns in microalgae: a comprehensive analysis of more than 2000 strains from the SAG culture collection. BMC Plant Biol 11:124

Leu E, Wiktor J, Soreide JE, Berge J, Falk-Petersen S (2010) Increased irradiance reduces food quality of sea ice algae. Mar Ecol Prog Ser 411:49-60

Lv X, Zou L, Sun B, Wang J, Sun M (2010) Variations in lipid yields and compositions of marine microalgae during cell growth and respiration, and within intracellular structures. J Exp Mar Biol Ecol 391:73-83

Mansour MP, Frampton DMF, Nichols PD, Volkman JK, Blackburn SI (2005) Lipid and fatty acid yield of nine stationary-phase microalgae: Applications and unusual C-24-C-28 polyunsaturated fatty acids. J Appl Phycol 17:287-300

Marshall JA, Nichols PD, Hallegraeff GM (2002) Chemotaxonomic survey of sterols and fatty acids in six marine raphidophyte algae. J Appl Phycol 14:255-265

Mayzaud P, Claustre H, Augier P (1990) Effect of variable nutrient supply on fatty-acid composition of phytoplankton grown in an enclosed experimental ecosystem. Mar Ecol Prog Ser 60:123-140

Meiser A, Schmid-Staiger U, Trosch W (2004) Optimization of eicosapentaenoic acid production by Phaeodactylum tricornutum in the flat panel airlift (FPA) reactor. J Appl Phycol 16:215-225

Milledge JJ (2011) Commercial application of microalgae other than as biofuels: A brief review. Rev Environ Sci Bio-Technol 10:31-41

Mostaert AS, Karsten U, Hara Y, Watanabe MM (1998) Pigments and fatty acids of marine raphidophytes: A chemotaxonomic re-evaluation. Phycol Res $46: 213-220$

Nichols DS, Nichols PD, McMeekin TA (1993) Polyunsaturated fatty-acids in Antarctic bacteria. Antarct Sci 5:149-160

Nishida I, Murata N (1996) Chilling sensitivity in plants and cyanobacteria: The crucial contribution of membrane lipids. Annu Rev Plant Physiol Plant Mol Biol 47:541-568

Ollis TE, Meyer BJ, Howe PRC (1999) Australian food sources and intakes of omega- 6 and omega-8 polyunsaturated fatty acids. Ann Nutr Metab 43:346-355

Otero A, García D, Fábregas J (1997) Factors controlling eicosapentaenoic acid production in semicontinuous cultures of marine microalgae. J Appl Phycol 9:465-469

Raven JA, Geider RJ (1988) Temperature and algal growth. New Phytol 110:441-461

Rousch J (2003) Changes in fatty acid profiles of thermo-intolerant and thermotolerant marine diatoms during temperature stress. J Exp Mar Biol Ecol 295:145-156

Sinclair R (2000) Good, bad or essential fats: what is the story with Omega-3? Nutr Food Sci 30:178-182

Teoh ML, Chu WL, Marchant H, Phang SM (2004) Influence of culture temperature on the growth, biochemical composition and fatty acid profiles of six Antarctic microalgae. J Appl Phycol 16:421-430

Thomas DN, Dieckmann GS (2002) Antarctic sea ice - a habitat for extremophiles. Science 295:641-644

Thompson PA, Harrison PJ, Whyte JNC (1990) Influence of irradiance on the fatty-acid composition of phytoplankton. J Phycol 26:278-288

Thompson PA, Guo MX, Harrison PJ, Whyte JNC (1992) Effects of variation in temperature. II. On the fatty acid composition of eight species of marine phytoplankton. J Phycol 28:488-497

Tonon T, Harvey D, Larson TR, Graham IA (2002) Long chain polyunsaturated fatty acid production and partitioning to triacylglycerols in four microalgae. Phytochemistry 61:15-24

Tzovenis I, DePauw N, Sorgeloos P (1997) Effect of different light regimes on the docosahexaenoic acid (DHA) content of Isochrysis-aff-galbana (clone T-ISO). Aquacult Int 5:489-507

Uauy R, Mena P, Rojas C (2000) Essential fatty acids in early life: Structural and functional role. Proc Nutr Soc 59:3-15

van de Poll WH, van Leeuwe MA, Roggeveld J, Buma AGJ (2005) Nutrient limitation and high irradiance acclimation reduce PAR and UV-induced viability loss in the Antarctic diatom Chaetoceros brevis (Bacillariophyceae). J Phycol 41:840-850

van de Poll WH, Visser RJW, Buma AGJ (2007) Acclimation to a dynamic irradiance regime changes excessive irradiance sensitivity of Emiliania huxleyi and Thalassiosira weissflogii. Limnol Oceanogr 52:1430-1438 van Leeuwe MA (1997) A barren ocean: Iron and light interactions with phytoplankton growth in the Southern Ocean. Thesis, University of Groningen, Diss. Ph. D

van Leeuwe MA, Villerius LA, Roggeveld J, Visser RJW, Stefels J (2006) An optimized method for automated analysis of algal pigments by HPLC. Mar Chem 102:267-275

Viso A, Marty J (1993) Fatty acids from 28 marine microalgae. Phytochemistry 34:1521-1533

Volkman JK, Jeffrey SW, Nichols PD, Rogers Gl, Garland CD (1989) Fatty-acid and lipid-composition of 10 species of microalgae used in mariculture. J Exp Mar Biol Ecol 128:219-240

Watanabe T, Kitajima C, Fujita S (1983) Nutritional values of live organisms used in Japan for mass propagation of fish: a review. Aquaculture 34:115-143

Yongmanitchai W, Ward OP (1991) Growth of and omega-3-fatty-acid production by Phaeodactylum tricornutum under different culture conditions. Appl Environ Microbiol 57:419-425

Zhukova NV (2004) Changes in the lipid composition of Thalassiosira pseudonana during its life cycle. Russ J Plant Physiol 51:702-707

Zhukova NV (2007) Changes in the fatty acid composition of symbiotic dinoflagellates from the hermatypic coral Echinopora lamellosa during adaptation to the irradiance level. Russ J Plant Physiol 54:763-769

doi:10.1186/2191-0855-3-26

Cite this article as: Boelen et al:: On the potential application of polar and temperate marine microalgae for EPA and DHA production. AMB Express 2013 3:26

\section{Submit your manuscript to a SpringerOpen ${ }^{\odot}$ journal and benefit from:}

- Convenient online submission

- Rigorous peer review

- Immediate publication on acceptance

- Open access: articles freely available online

- High visibility within the field

- Retaining the copyright to your article

Submit your next manuscript at $>$ springeropen.com 